
薬物間相互作用の定量的予測

○伊藤 清美 ${ }^{1)} 、$ 金光 真一 ${ }^{1)}$ 、廣田 徳子 ${ }^{1)}$ 、中島 由起子 ${ }^{1)}$ 、岩坪 隆史 ${ }^{2)} 、$ Carol E.Green ${ }^{3)}$ 、Charles A.Tyson ${ }^{3)}$ 、島田 典招4)、鈴木 洋史 ${ }^{1)}$ 、杉山 雄一1)

${ }^{1)}$ 東京大学薬学部製剂設計学教室、 ${ }^{2)}$ 山之内製薬（株）、

${ }^{3)}$ SRI International、 ${ }^{4)}$ 第一化学薬品

\title{
QUANTITATIVE PREDICTION OF IN VIVO METABOLIC CLEARANCE AND DRUG-DRUG INTERACTIONS IN HUMANS BASED ON IN VITRO STUDIES
}

\author{
Kiyomi ITO $^{1)}$, Shin-ichi KANAMITSU ${ }^{1)}$, Noriko HIROTA ${ }^{1)}$, Yukiko NAKAJIMA ${ }^{1)}$, \\ Takafumi IWATSUBO ${ }^{2)}$, Carol E.Green ${ }^{3)}$, Charles A.Tyson ${ }^{3)}$, Noriaki SHIMADA ${ }^{4)}$, \\ Hiroshi SUZUKI ${ }^{1)}$, and Yuichi SUGIYAMA ${ }^{1)}$ \\ ${ }^{1)}$ Dept. of Pharmaceutics., Fac. of Pharm. Sci., Univ. of Tokyo, Tokyo 113, ${ }^{2)}$ Yamanouchi \\ Pharmaceutical Co., Ltd., ${ }^{3)}$ SRI International, ${ }^{4)}$ Daiichi Pure Chemicals Co., Ltd.
}

【目的】近年、ヒト肝ミクロソーム、各種ヒト P450 発現系などの入手が比較的容易になってき たことから、これらを用いた in vitro 代謝試験に 基づいて in vivoに抒ける肝代謝能を予測しよう という試みが盛んに行われている年3)。本研究では、 in vitro デー夕に基づいて in vivo 薬物体内動態を 定量的に予測するための方法論を確立することを 目的とし、代謝に非線形性がみられる場合などを 含めて具体的な検討を行った。また、ヒト肝ミク ロソーム等を用いた in vitro 試験から in vivo での 薬物間相互作用を定量的に予測することを試み、 予測性の向上を目的として、肝臓内における阻害 剂の非結合型濃度を見積るための方法論について 検討した。

【方法】1. In vivo ヒト肝代謝能の in vitro デー夕 からの予測 チトクローム P450 が関与する多く の代謝反応について、文献情報を基に in vitro 代 謝固有クリアランス (CLint, in vitro) を算出し、体 内動態パラメータから dispersion modelにしたが って算出した in vivo 代謝固有クリアランス (CLint,in vivo) と比較した。また、痴呆症状改善 薬として開発中の YM796について、初回通過代 謝の非線形性を考慮した解析により、ラット、イ ヌ、およびヒトにおける経口投与後の AUC およ びバイオアベイラビリティを in vitro 代謝試験デ ータから予測することを試みた ${ }^{4,5)}$ 。 2. In vivo ヒト薬物間相互作用の in vitro デー夕からの予測

P450 代謝における競合阻害が関与すると考え
られる種々の薬物間相互作用について、阻害剤の 肝蔵中と門脈血中の非結合型濃度が等しいと仮定 し、in vitro 代謝試験により得られた阻害定数 (Ki) を基に in vivo での AUC 上昇率の予測を試み た ${ }^{3,6,7)}$ 。また、ラット遊離肝細胞を用いた取り込 み試験において阻害剂の能動輸送性を評価し、得 られた肝臓中 / 血漿中非結合型濃度比を用いて子 測性の再検討を行った。

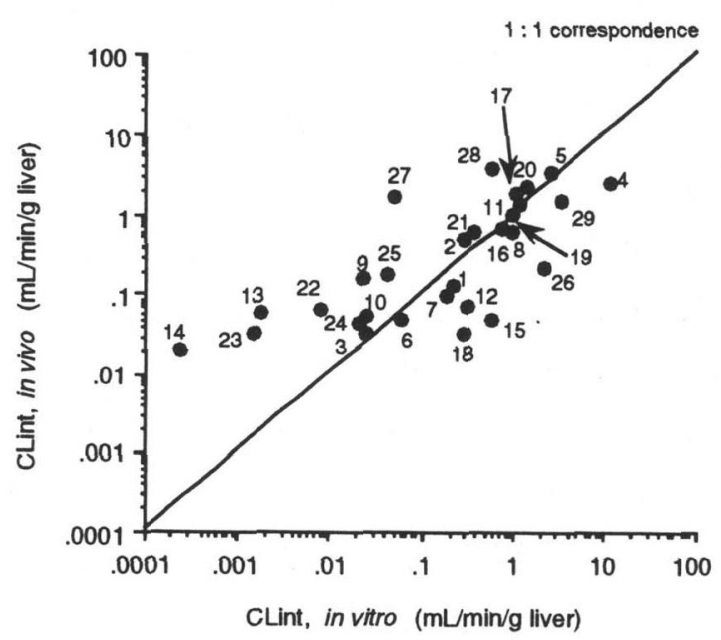

Fig.1 Comparison of CLint,in vitro with CLint,in vivo in humans. (1)alprazolam; (2)diazepam; (3)dofetilide; (4)imipramine; (5)lidocaine; (6)loxtidine; (7) $\alpha$-hydroxymetoprolol; (8)O-demethylmetoprolol; (9)hydroxymethylmexiletine; (10)p-hydroxymexiletine; (11)phenacetin; (12)quinidine; (13) 1,3-dimethyluric acid +1-methylxanthine; (14)3-methylxanthine; (15)tolbutamide; (16)norverapamil (R-form); (17)D-617 (R-form); (18)D-703 (R-form); (19)norverapamil (S-form); (20)D-617 (S-form); (21)D-703 (S-form); (22)6-hydroxywarfarin (R-form); (23)7-hydroxywarfarin (R-form); (24)6-hydroxywarfarin (S-form); (25)7-hydroxywarlarin (S-form); (26)torsemide; (27)S-mephenytoin; (28)fentanyl; (29)triazolam. 
【結果及び考察】1. In vivo ヒト肝代謝能の in vitro データからの予測 多くの代謝反応について CLint,in vitro と CLint,in vivo とは良好な一致を示 したが、中には 10 倍以上の差がみられるものも あった (Fig.1) ${ }^{2.3)}$ 。この原因としては、小腸に扔け る初回通過代謝の関与あるいは肝代謝の個人差等 が考えられる。また、YM796の初回通過代謝に 関して、門脈への吸収速度を考慮することにより、 代謝が非線形の場合にも in vitro デー夕からの予 測が可能であることが示唆された (Fig. 2$)^{4,5)}$

2. In vivo ヒ卜薬物間相互作用の in vitro デー夕か らの予測 Tolbutamide-Sulfaphenazole、TriazolamKetoconazole 等の相互作用については定量的予測 が可能であったが、in vivo 薬物間相互作用が過小 評価される組み合わせもあった Erythromycin 等の阻害剂について、ラット遊離肝 細胞における能動輸送性は低く、肝臟中非結合型
(A)

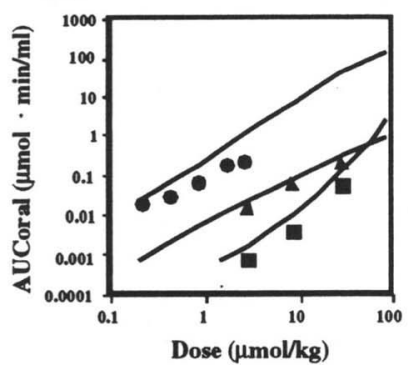

(B)

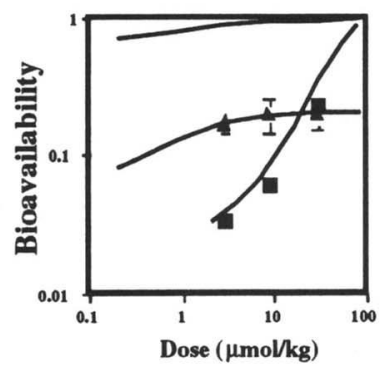

Fig.2 Comparison of the predicted and the observed values for AUCoral (A) or bioavailability (B) of YM796 in rats, dogs and humans.

The solid lines represent the predicted curves based on the kinetic parameters obtained from the in vitro metabolism studies. $\square$ : observed data for rats; $\mathbf{\Delta}$ : observed data for dogs; and 0 : observed data for humans.

濃度を用いても予測性に大きな変化はみられなかっ た。予測性の向上のために、今後、小腸での吸収 過程に扔ける薬物間相互作用も考慮する必要があ ると考えられる。

[ABSTRACT] The in vitro intrinsic clearances (CLint, in vitro) of P450-mediated reactions obtained by using human liver microsomes were compared with the in vivo intrinsic clearances (CLint,in vivo) which were calculated from pharmacokinetic data in literature. Although CLint, in vitro and CLint, in vivo agreed well with each other for most of the drugs investigated, more than 10-fold differences were observed for some drugs, indicating the possible involvement of the first-pass metabolism in the gut and/or interindividual variability in the hepatic metabolism. The AUCoral and bioavailability of YM796, a compound being developed for the treatment of dementia, were well predicted from in vitro metabolic studies taking the non-linear first-pass metabolism into consideration. Furthermore, we have tried to predict in vivo drug-drug interactions from in vitro data on drug metabolism obtained from the literature. Assuming the same unbound concentration of the inhibitor in the liver and in plasma, the degree of increase in the AUC caused by the metabolic inhibition was underestimated for some of the drug combinations. The transport study using isolated rat hepatocytes indicated that the contribution of the active transport of the inhibitors such as quinidine, erythromycin etc. into the hepatocytes is not so large. The drug-drug interactions involving the gastrointestinal absorption process may have to be considered for the more precise prediction.

[REFERENCES] 1) Iwatsubo T, Hirota N, Ooie T, Suzuki H, Sugiyama Y: Prediction of in vivo drug disposition from in vitro data based on physiological pharmacokinetics. Biopharm. Drug Dispos. 17: 273-310 (1996). 2) Iwatsubo T, Hirota N, Ooie T, Suzuki H, Shimada N, Chiba K, Ishizaki T, Green CE, Tyson CA, Sugiyama Y: Prediction of in vivo drug metabolism in the human liver from in vitro metabolism data. Pharmacol. Ther. 73: 147-171 (1997). 3) Ito K, Iwatsubo T, Kanamitsu S, Nakajima Y, Sugiyama Y: Quantitative prediction of in vivo drug clearance and drug interactions from in vitro data on metabolism together with binding and transport. Ann. Rev. Pharmacol. Toxicol. (1998). 4) Iwatsubo T, Suzuki H, Shimada N, Chiba K, Ishizaki T, Green CE, Tyson CA, Yokoi T, Kamataki T, Sugiyama Y: Prediction of in vivo hepatic metabolic clearance of YM796 from in vitro data by use of human liver microsomes and recombinant P-450 isozymes. J. Pharmacol. Exp. Ther. in press. 5) Iwatsubo T, Suzuki H, Sugiyama Y: Prediction of species differences (rats, dogs, humans) in the in vivo metabolic clearance of YM796 by the liver from in vitro data. J. Pharmacol. Exp. Ther. in press. 6) 杉山雄一, 岩坪隆史: 薬物相互作用に 伴う体内動態変動. 薬物動態 11:286-293 (1996). 7) Sugiyama Y, Iwatsubo T, Ueda K, Ito K: Strategic proposals for avoiding toxic interactions with drugs for clinical use during development and after marketing of a new drug: Pharmacokinetic consideration. J. Toxicol. Sci. 21: 309-316 (1996). 